Acta Theriologica 39 (1): 73-82, 1994.

PL ISSN 0001-7051

\title{
Moose browsing on pine and willow in the Biebrza Valley, Poland
}

\author{
Anetta BORKOWSKA and Agnieszka KONOPKO
}

\begin{abstract}
Borkowska A. and Konopko A. 1994. Moose browsing on pine and willow in the Biebrza Valley, Poland. Acta theriol. 39: 73-82.

Utilization of browse supply and moose Alces alces Linnaeus, 1758 browsing intensity in relation to tree height $(0.5-3.0 \mathrm{~m})$ were estimated for Scots pine in thickets and willow in willow-birch shrubs. The thickets examined provided different browse resources $(0.5,2.0$ and $3.2 \mathrm{t}$ dry wt/ha) and the highest utilization (about $50 \%$ ) was found in the poorest one (thicket 1). In the willow-birch shrubs the use of browse was high and amounted to $85 \%$ of total production in both the winter periods studied. The number and increase of biomass of browsed twigs per stem (or plot) was generally associated with the increase of tree height. Browsing intensity depended on the tree height. Pines of $1.5-1.99 \mathrm{~m}$ height were characterized by the greatest browse utilization $(76.3 \%)$. Moose removed significantly more biomass and twigs from pines growing in the central zone of the thicket 1 than from those growing in the marginal zone. However, in the willow-birch shrubs the utilization of all tree height classes was above $70 \%$ of the production and moose browsed not only the last year's growth of shoots but also that of earlier years.

Institute of Biology, Warsaw University, Branch in Białystok, ul. Świerkowa 20B, 15-950 Białystok, Poland

Key words: Alces alces, browsing, the Biebrza Valley, Poland
\end{abstract}

\section{Introduction}

Scots pine Pinus sylvestris and willow Salix spp. are a typical winter food of moose Alces alces Linnaeus, 1758 in Europe (Dunin and Januško 1979, Cederlund et al. 1980, Hagen 1983, Kozlo 1983, and others). Studies carried out in Poland (Morow 1976) indicated high moose preferences for pine and willow in winter. However, Dzięciołowski (1974) classified Pinus sylvestris as a food of second choice.

The Biebrza river valley is the main refuge of moose in Poland: about 500-600 animals were counted on 170000 ha of its surface in 1989-1991 (Gębczyńska and Raczyński 1993). Pine forests, thickets and plantations appear to be important to moose only in the winter season. In willow-birch shrubs moose often feeds all year round (Gębczyńska and Raczyński 1983, 1989). Moose browsing on pine and willow has not been estimated in the Biebrza Valley until now. Moose starts to be seriously damaging to forest regeneration, thickets and plantations by browsing 
shoots, stripping bark and breaking young trees (Szukiel 1984). On the other hand regular and intensive grazing of willow can probably set back an expansion of willow-birch shrubs in open sedge communities (Pałczyński 1985). These problems are important in protection of natural swamps and forests, and in management of the moose population in the Biebrza Valley.

The purpose of the present study was (1) to estimate the browse supply for moose in thickets and willow-birch shrubs and (2) to estimate an extent of the biomass removed by moose browsing on pine and willow growth at the richest feeding grounds in the Biebrza Valley.

\section{Study area}

The Biebrza Valley (at present the Biebrza National Park) is a large area of peatlands preserved in its natural state. It is located in north-eastern Poland $\left(53^{\circ} 21^{\prime} \mathrm{N}, 22^{\circ} 38^{\prime} \mathrm{E}\right)$. Studies were carried out in the southern part of the valley (the southern basin). The study area included pine thickets on mineral soils and willow-birch shrubs on peatlands (Fig. 1). Thickets of the fresh pine forest (Vaccinio myrtilli-Pinetum) were 10-20 years old and had a small admixture of Betula spp. (Operat... 1981). Willow-birch shrubs (the community with Salix cinerea and Betula pubescens) were a succession stage towards Betuletum pubescentis-verrucosae. Prevailing species include: B. pubescens, B. pendula, B. humilis, S. cinerea, S. pentadra, S. rosmarinifolia and S. amygdalina (Pałczyński 1984, 1985).

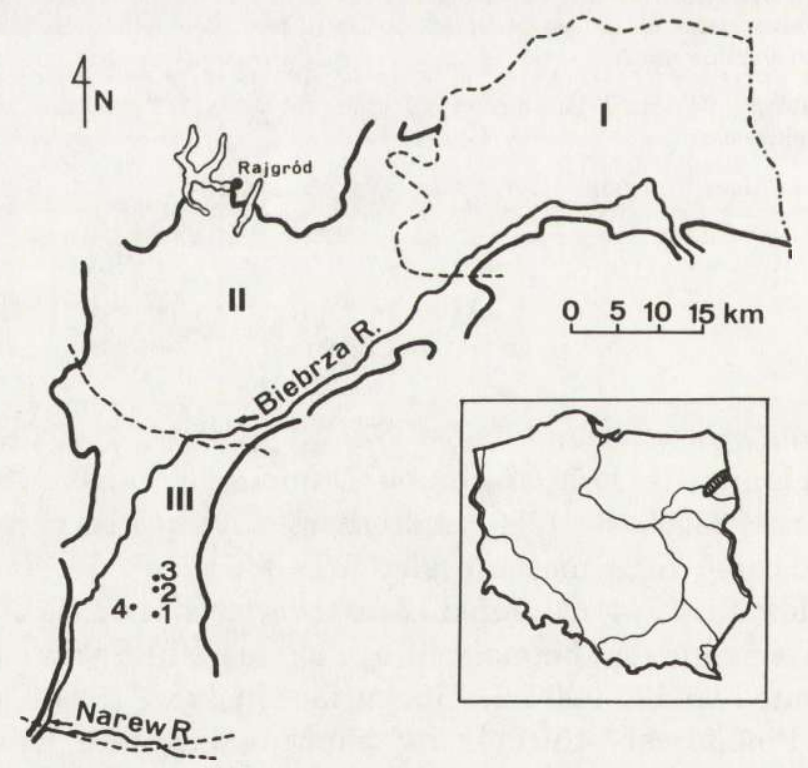

Fig. 1. Geographical location of study area. Solid lines - the Biebrza Valley border (plateau edge); broken lines - the border of the basins: northern (I), middle (II) and southern (III) (after Liwski et al. 1984, modified); 1, 2, 3 - thickets; 4 - willow-birch shrubs. 


\section{Material and methods}

Studies were carried out in 1989, 1990 and 1992. Firstly a tree height structure was estimated in 25 unfenced plots $(5 \times 5 \mathrm{~m})$ in thickets $(1,2$ and 3$)$ and 100 unfenced plots $(1 \times 1 \mathrm{~m})$ in willow-birch shrubs. Pines were divided into five tree height classes (class I: $0.5-0.99 \mathrm{~m}$, class II: $1.0-1.49 \mathrm{~m}$, class III: $1.5-1.99 \mathrm{~m}$, class IV: $2.0-2.49 \mathrm{~m}$, class V: $2.5-3.0 \mathrm{~m}$ ) and willow into the same four classes (I-IV).

Two methods were used to estimate browse supply in autumn. The harvesting method was used in thicket 1 and the willow-birch shrubs (Dzięciołowski 1969, Bobek and Dzięciołowski 1972, modified). The shape and size of plots were changed for $1 \times 1 \mathrm{~m}$ in willow shrubs and sample pines were taken in the thicket. Twigs were considered to be current growths of trees and shrubs from the previous vegetation season. They were cut from 25 pines and 25 open plots of willow shrubs. Fresh shoots were weighed to $0.1 \mathrm{~g}$, then dried at $65^{\circ} \mathrm{C}$ for $48 \mathrm{~h}$ and reweighed with the same accuracy. Coefficient W (dry matter/fresh matter of sample) was equal $0.38 \pm 0.03$ for Pinus sylvestris and 0.49 \pm 0.02 for Salix spp. We used it to calculate the average dry matter of browse per stem (plot). Twig weight-diameter relationships were also found for these two species (Telfer 1969). The regression equations took the following forms: for pine (diam. 0.5-7 mm): $y=0.78 x^{1.22}(r=0.99)$ and for willow (diam. 0.5-5 mm): $y=0.13 x^{1.92}(r=0.99)$, where: $y$ - twig weight (g dry wt), $x$ - twig diameter $(\mathrm{mm})$, $r$-correlation coefficient.

The second method of an estimation of browse supply was the twig count method, used in the thicket 2 and 3 (Shafer 1963, modified). Twigs were not cut, but they were only counted and diameters of five random current growths were measured on about 100 sample trees. The average biomass of browse per stem was estimated with the use of the twig-weight diameter relationship and the number of twigs. Then it was converted to $\mathrm{kg}$ dry $\mathrm{wt} / \mathrm{ha}$.

The utilization of winter browse was appraised in two zones (central and marginal) of the thickets in early spring. In the willow-birch shrubs the estimation was made in 1990 and 1992 (willow-birch shrubs 1 and 2). The number of browsed twigs and shoots was counted on stem (plot) and their diameter points at browsing were measured (Shafer 1963). The browse consumption ( $\mathrm{g}$ dry wt/stem or plot) was estimated on the basis of the weight-diameter relationship.

The data were not normally distributed (tested by $\chi^{2}$-test at $p=0.05$ ). Therefore, Kruskal-Wallis one-way analysis by ranks was performed to test the effect of tree height on the browse supply, biomass and number of browsed twigs. Kruskal-Wallis analysis was also used to test the differences in browsed biomass and twigs between the marginal and central zone of thickets.

\section{Results}

Browse utilization by moose in the pine thickets and the willow-birch shrubs

The pine thickets of the Biebrza Valley differed from each other according to their browse supply $(H=58.21, p<0.0001)$ and browse consumed by moose in the winter period $(H=52.57, p<0.0001)$ (Table 1$)$. An intensive feeding was observed in thicket 1 every year: $89 \%$ of trees were browsed. This thicket had the smallest food resources probably because of the high utilization (about $50 \%$ of the browse supply) and lower biomass production per stem (Table 2). In the other two thickets a small percentage of browsed plants was found $(10 \%$ and $2 \%$ in the thickets 2 and 3 , respectively). Their browse supply was enormous and their biomass production per stem was the highest (Tables 1 and 2).

The utilization of browse resources in the willow-birch shrubs was very high and equal in both the winter periods studied (Kruskal-Wallis test, $p>0.05$ ). This 
Table 1. Browse supply and its utilization in the thickets and the willow-birch shrubs in the southern basin of the Biebrza Valley, Poland. ${ }^{1}$ Mean value for data collected in 1990 and 1992 ; for $100 \%$ growth of vegetation.

\begin{tabular}{|c|c|c|c|}
\hline Stands & $\begin{array}{c}\text { Browse supply } \\
\text { (kg dry wt/ha } \pm \mathrm{SD})\end{array}$ & $\begin{array}{l}\text { Browse consumed } \\
(\mathrm{kg} \text { dry wt/ha } \pm \mathrm{SD})\end{array}$ & $\begin{array}{c}\text { Utilization } \\
(\%)\end{array}$ \\
\hline Thicket 1 & $508.08 \pm 115.23$ & $243.12 \pm 61.72$ & 47.9 \\
\hline Thicket 2 & $2019.87 \pm 596.12$ & $195.55 \pm 57.35$ & 9.7 \\
\hline Thicket 3 & $3212.63 \pm 938.18$ & $37.69 \pm 24.67$ & 1.2 \\
\hline Willow-birch shrubs ${ }^{1}$ & $671.69 \pm 32.17$ & $566.09 \pm 22.05$ & 84.3 \\
\hline
\end{tabular}

Table 2. Average browse production of Sctos pine (g dry wt/stem) and willow (g dry wt/m $\mathrm{m}^{2}$ ) in relation to the tree height classes. $n$ - number of pine stems or willow plots, $p$ - significance level in Kruskal-Wallis test.

\begin{tabular}{|c|c|c|c|c|c|c|c|}
\hline \multirow{2}{*}{ Stands } & & \multicolumn{5}{|c|}{ Class of tree height } & \multirow{2}{*}{$p<$} \\
\hline & & I & II & III & IV & V & \\
\hline \multirow[t]{3}{*}{ Thicket 1} & $\mathrm{~g}$ & 27.7 & 120.5 & 65.9 & 151.4 & 202.7 & 0.05 \\
\hline & SD & 10.3 & 135.7 & 33.0 & 100.3 & 139.6 & \\
\hline & $n$ & 5 & 6 & 8 & 3 & 2 & \\
\hline \multirow[t]{3}{*}{ Thicket 2} & g & 22.6 & 69.6 & 163.8 & 221.8 & 272.0 & 0.0001 \\
\hline & SD & 16.5 & 40.3 & 106.8 & 124.4 & 129.5 & \\
\hline & $n$ & 24 & 25 & 25 & 23 & 13 & \\
\hline \multirow[t]{3}{*}{ Thicket 3} & g & 49.4 & 154.0 & 412.6 & 658.9 & 693.8 & 0.0001 \\
\hline & SD & 38.0 & 90.3 & 202.0 & 371.2 & 250.4 & \\
\hline & $n$ & 25 & 25 & 25 & 23 & 21 & \\
\hline$p<$ & & 0.0001 & 0.001 & 0.0001 & 0.0001 & 0.0001 & \\
\hline \multirow[t]{3}{*}{ Willow-birch shrubs } & $\mathrm{g}$ & 40.2 & 63.8 & 71.1 & 80.1 & - & 0.05 \\
\hline & $\mathrm{SD}$ & 13.1 & 17.2 & 13.8 & 15.7 & - & \\
\hline & $n$ & 4 & 4 & 7 & 6 & - & \\
\hline
\end{tabular}

amounted $86.4 \%$ and $82.4 \%$ of biomass production in 1990 and 1992 , respectively. Therefore the data were pooled and given together in Table 1.

\section{Moose browsing on Scots pine}

Moose contacts were observed in the zone $0.5-3.0 \mathrm{~m}$. Diameters at browsing points were contained between $0.5 \mathrm{~mm}$ and $7 \mathrm{~mm}$. Moose ate on average 3-18 twigs per stem.

There were significant differences in biomass of browsed twigs per stem in relation to the tree height in each thicket and among thickets in each class (Table 3 ). The increase of eaten twig biomass was positively related to increasing height 


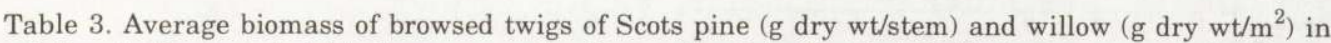
relation to the tree height classes. $p$ - significance level in Kruskal-Wallis test, ns - not significant difference $(p \geq 0.05)$.

\begin{tabular}{|c|c|c|c|c|c|c|c|}
\hline \multirow{2}{*}{ Stands } & & \multicolumn{5}{|c|}{ Class of tree height } & \multirow{2}{*}{$p<$} \\
\hline & & I & II & III & IV & V & \\
\hline \multirow[t]{2}{*}{ Thicket 1} & $\mathrm{~g}$ & 17.6 & 36.4 & 50.3 & 68.1 & 78.3 & \multirow[t]{2}{*}{0.0001} \\
\hline & $\mathrm{SD}$ & 21.1 & 35.0 & 40.4 & 63.8 & 69.6 & \\
\hline \multirow[t]{2}{*}{ Thicket 2} & g & 4.4 & 5.0 & 13.1 & 42.6 & 18.5 & \multirow[t]{2}{*}{0.0001} \\
\hline & SD & 12.0 & 12.6 & 25.1 & 37.1 & 21.4 & \\
\hline \multirow[t]{2}{*}{ Thicket 3} & $\mathrm{~g}$ & 0.1 & 0 & 0.9 & 1.1 & 26.1 & \multirow[t]{2}{*}{0.0001} \\
\hline & $\mathrm{SD}$ & 0.6 & & 3.9 & 4.1 & 69.7 & \\
\hline$p<$ & & 0.0001 & 0.0001 & 0.0001 & 0.0001 & 0.0001 & \\
\hline \multirow[t]{2}{*}{ Willow-birch shrubs 1} & g & 42.4 & 53.3 & 56.6 & 71.6 & - & \multirow[t]{2}{*}{0.0001} \\
\hline & SD & 17.2 & 22.7 & 19.7 & 20.9 & - & \\
\hline \multirow[t]{2}{*}{ Willow-birch shrubs 2} & g & 33.4 & 57.5 & 60.7 & 56.8 & - & \multirow[t]{2}{*}{0.05} \\
\hline & $\mathrm{SD}$ & 19.6 & 26.6 & 25.8 & 19.6 & - & \\
\hline$p<$ & & ns & ns & $\mathrm{ns}$ & 0.05 & & \\
\hline
\end{tabular}

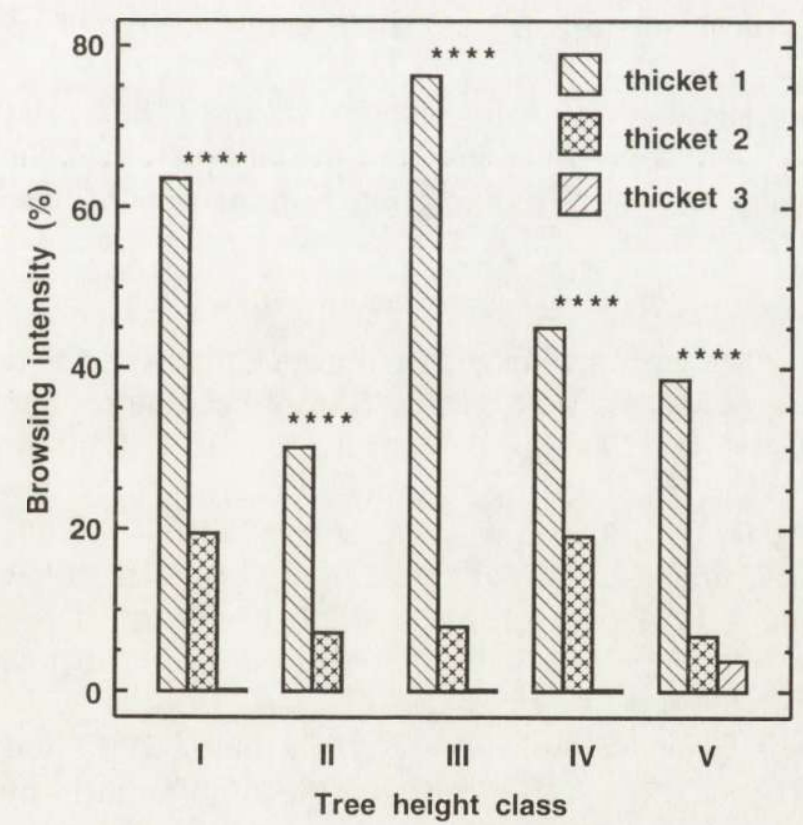

Fig. 2. Moose browsing intensity $(\%)$ on pine stems in tree height classes in the Biebrza Valley, Poland. Significance levels in Kruskal-Wallis test are given above the bars, ${ }^{* * * *}-p<0.0001$. 


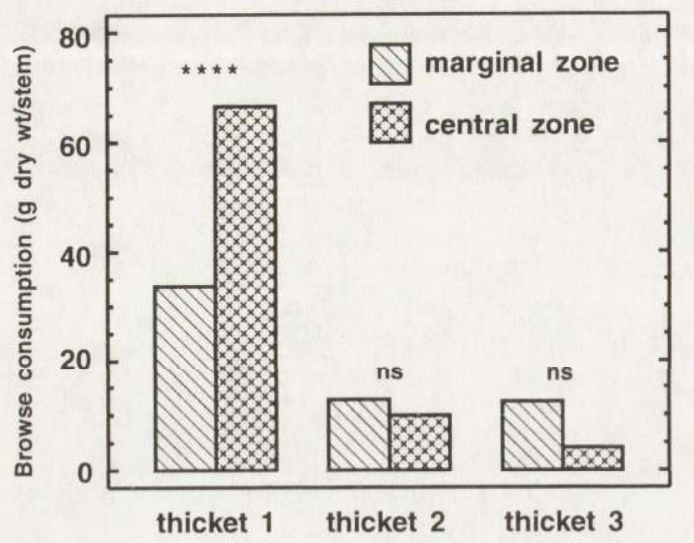

Fig. 3. Browse consumption (g dry wt/stem) in the marginal and central zone of thickets in the Biebrza Valley, Poland. Significance levels in Kruskal-Wallis test are given above the bars, ns - not significant $(p \geq 0.05), * * * *-p<0.0001$.

of the tree. However, there were no moose bites in the class II (1.0-1.49 m) of the thicket 3 .

Browsing intensity (browse consumed/browse available) on pine stems was significantly different $(p<0.0001)$ in each height class (Fig. 2). In thicket 1 moose consumed at least $30 \%$ of browse supply from each plant and up to $76.3 \%$ from pines of class III (1.5-1.99 m). Lower utilization of trees of 1.0-1.49 m height (class II) could depend on their high biomass production (Table 2). In thicket 2 the browsing intensity exceeded the mean value for the whole thicket only in classes I and IV. However, in thicket 3 the greatest degree of browse utilization was $3.8 \%$ (class V) (Fig. 2).

Moose removed significantly more biomass $(H=29.13, p<0.0001)$ and twigs $(H=26.21, p<0.0001)$ from pines growing in the central zone of thicket 1 than from pines growing in the marginal zone. Similar dependence was absent in thickets 2 and 3 (Fig. 3 ).

\section{Moose browsing on willow}

Willow twigs were browsed from all marked plots in the zone $0.5-2.5 \mathrm{~m}$. Diameter of bites ranged from $0.5 \mathrm{~mm}$ to $5 \mathrm{~mm}$. Feeding on birch was recorded only occasionally so the species was disregarded. Significant differences were found in biomass of browsed twigs among tree height classes for willow-birch shrubs 1 $(H=23.41, p<0.0001)$ and willow-birch shrubs $2(H=10.60, p<0.05)$. The amount of biomass removed differed significantly between willow-birch shrubs 1 and 2 only in class IV $(H=6.15, p<0.05)$ (Table 3$)$. The average brovse consumption per plot increased with the increase in shrub height and brovse production (Tables 2 and 3 ).

Browsing intensity on willow was very high (above 70\%) and similar in tee height classes I, II and III (no statistically significant differences by Kruskal-Wallis test). In class I $(0.5-0.99 \mathrm{~m})$ of willow-birch shrubs 1 the utilization was eren greater than production (105.5\%). It could be a result of browsing not only in the last year of growth of shoots but also earlier (Fig. 4). 




Fig. 4. Moose browsing intensity $(\%)$ of willow plots $\left(1 \mathrm{~m}^{2}\right)$ in tree height classes in the Biebrza Valley, Poland. Significance levels in Kruskal-Wallis test are given above the bars, ${ }^{*}-p<0.05$.

\section{Discussion}

Pine thickets are the richest feeding grounds in the southern basin of the Biebrza Valley. As compared to other age stands of forest they provide enormous browse supply which could be consumed by moose (Borkowska and Konopko 1994). High utilization of browse resources was observed in the poorest of the studied thickets. Pines growing slowly in unproductive habitats were exposed to moose browsing longer during their life-span, than pines growing rapidly in more productive habitats. They generally suffer more from moose browsing than pines in habitats where the possibility for growth is better (Danell et al. 1991). The thickets studied grew on poor soils (sand dunes) and the moose density was high: 3.1-5.0 individuals/1000 ha in the southern basin of the Biebrza Valley (Gębczyńska and Raczyński 1983). It seems therefore clear that a high degree of pine thicket utilization was a result of a combined effect of high moose density and poor growth of trees due to low productivity of the habitat.

Moose browsed up to $85 \%$ of willow production estimated in early spring but this could be a result of feeding during all the previous vegetation period. It seems that the willow-birch shrubs are the main feeding grounds providing deciduous browse in the Biebrza Valley.

In the southern basin of the Biebrza Valley seasonal migrations were observed between the areas rich in summer food (sedge patches) and areas abundant in 
winter food (thickets and pine plantations) (Gębczyńska and Raczyński 1984, 1989). Therefore, intensive browsing in one of the studied thickets may also be a result of the location of the thicket among less productive older tree stands, and the moose migration pattern from summer to winter feeding grounds.

The utilization of the same species differs regionally, due to behavioural response to differences in food supply (Sæther and Andersen 1991). Moose fed in a thicket for a long time due to the lack of other forage (Dunin and Januško 1979). We could therefore find significant differences in browse consumption between the marginal and the central zone in the thicket situated among poor tree stands. Moose presumably preferred to feed in the middle of the thicket to be safe from predators. This natural behaviour could not be detected in rich pine habitats because of the small biomass utilization and its random removal. However, we cannot answer the question how behavioural factors (e. g. hiding from enemies, migrations) influence moose foraging behaviour and the optimal foraging model based on time-energy consideration (Belovsky 1981, Owen-Smith and Novellie 1982).

Browsing intensity on pine and willow depends on the tree height. Dunin and Januško (1979) found that trees 1.7-3.5 m high were used by moose more often than others. The amount of available biomass and the size of current annual shoots may also explain the variation in twig consumption by moose. A moose removes more from pines with a high standing crop of available twigs than those with a smaller amount, and it prefers trees with large twigs (Danell et al. 1991). In the studied thickets, pines with a high biomass production were the highest ones (1.5-3.0 m).

Moose browsing can influence plants in different ways. The impact of foraging on trees is closely correlated with the amount of biomass removed (Vivås et al. 1991), tree species (Danell et al. 1985) and tree morphology (Danell et al. 1991). The removal of large quantities of biomass by moose browsing in the studied thickets will presumably result in lowering the quality of food and producing slender of twigs in the following seasons. This may also reduce the growth rate of pines.

Plant species which have a few large annual shoots of high quality will be more affected by herbivores than species having the same available biomass but with the smaller shoots of lower digestibility. On the other hand, there was no correlation between browsing intensity and the number of twigs per stem of willow (Wolff and Cowling 1981). Wolff (1978) suggested that willow shrubs were able to compensate for loss of biomass caused by overwinter browsing by increasing productivity of browse-damage stems. An increase of the number of shoots produced in response to browsing may be an adaptation to reduce the impact of further browsing (Vivås et al. 1991). Furthermore, lower shrubs of willow browsed from above usually grow laterally. However, browsing on lower and central branches of shrubs stimulate apical growth and shrubs assume tree shape (Faliński 1990). At present, we cannot confirm that regular and intensive grazing 
on willow can set back an expansion of shrubs, as Pałczyński (1985) suggested, even though we found high and similar browsing intensities on willow in both the periods studied. Further studies on this subject seem to be necessary with regard to plant defence systems against herbivores.

Acknowledgement: We would like to thank to Prof M. Gębczyński for his attention to our work and critical reading of the manuscript. We are also grateful to Prof N. Chapman and Dr M. Konarzewski for their linguistic corrections.

\section{References}

Belovsky G. E. 1981. Food plant selection by a generalist herbivore: the moose. Ecology 62: 1020-1030.

Bobek B. and Dzięciołowski R. 1972. Method of browse estimation in different types of forest. Acta theriol. 17: 171-186.

Borkowska A. and Konopko A. 1994. The winter browse supply for moose in different forest site-types in the Biebrza Valley, Poland. Acta theriol. 39: 67-71.

Cederlund G., Ljungqvist H., Markgren G. and Stålfelt F. 1980. Foods of moose and roe deer at Grimsö in Central Sweden - results of rumen content analysis. Viltrevy 11: 169-247.

Danell K., Huss-Danell K. and Bergström R. 1985. Interaction between browsing moose and two species of birch in Sweden. Ecology 66: 1867-1878.

Danell K., Nemelä P., Varvikko T. and Vuorisalo T. 1991. Moose browsing on Scots pine along a gradient of plant productivity. Ecology 72: 1624-1633.

Dunin V. F. and Januško A. D. 1979. Ocenka kormovoj bazy losja v lesnych ugod’jach. Uražaj, Minsk: 1-94. [In Russian]

Dzięciołowski R. 1969. Metody pomiaru zapasu żeru pędowego w zbiorowiskach leśnych. Ecol. pol. B. 15: $255-261$.

Dzięciołowski R. 1974. Selection of browse twigs by moose. Acta theriol. 19: 273-281.

Faliński J. B. 1990. Zarys ekologii. [In: Nasze drzewa leśne. Monografie popularnonaukowe. 13. Wierzby (Salix alba L., Salix fragilis L.). S. Białobok, ed]. Polish Sci. Publ., Warszawa - Poznań: 71-138.

Gębczyńska Z. and Raczyński J. 1983. Habitat use by moose in the Biebrza river valley. Proc. 16th IUGB Congr. Vysoké Tatry, Sterbské Pleso, ČSSR: 43-49. [In Russian with English summary]

Gębczyńska Z. and Raczyński J. 1984. Habitat preferences and population structure of moose in the Biebrza river valley. Acta zool. Fenn. 172: 93-94.

Gębczyńska Z. and Raczyński J. 1989. Distribution, population structure and social organization of moose in the Biebrza Valley, Poland. Acta theriol. 34: 195-217.

Gębczyńska Z. and Raczyński J. 1993. Problems of protection and management of moose and other game in the Biebrza National Park. Parki Narodowe i Rezerwaty Przyrody 12: 5-36. [In Polish with English summary]

Hagen Y. 1983. Elgens vinterbeiting i Norge. Viltrapport 26: 1-111.

Kozlo P. G. 1983. Ekologo-morfologičeskij analiz populjacii losja. Nauka i Technika, Minsk: 1-215. [In Russian]

Liwski S., Maciak F., Okruszko H., Churski T., Gotkiewicz J., Oświt J., Pacowski R., Szuniewicz J. and Żurek S. 1984. Characteristic of soil formation and soils and their evolution due to draining and different utilization. Pol. ecol. Stud. 10: 313-346.

Morow K. 1976. Food habits of moose from the Augustów forest. Acta theriol. 21: 101-116.

Operat glebowo-siedliskowy, Nadleśnictwo Trzcianne. 1981. Biuro Urządzania Lasu i Geodezji Leśnej, Oddział w Białymstoku, Białystok.

Owen-Smith N. and Novellie P. 1982. What should a clever ungulate eat? Am. Nat. 119: 151-178. 
Pałczyński A. 1984. Natural differentiation of plant communities in relation to hydrological conditions of the Biebrza Valley. Pol. ecol. Stud. 10: 347-385.

Pałczyński A. 1985. Succession trends in plant communities of the Biebrza Valley. Pol. ecol. Stud. 11: $5-20$.

Sæther B. E. and Andersen R. 1991. The relationship between a large herbivore, the moose, and its food resources: the importance of behavior in the dynamics of plant-herbivore interactions. Proc. Vth INTECOL Congr., Tsukuba and Yokohama 1990.

Shafer E. L. 1963. The twig-count method for measuring hardwood deer browse. J. Wildl. Manage. 27: 428-437.

Szukiel E. 1984. Szkody łowieckie w polskich lasach. Sylwan 3: 47-56.

Telfer E. S. 1969. Twig weight-diameter relationships for browse species. J. Wildl. Manage. 33: 917-921.

Vivås H. J., Sæther B.-E. and Andersen R. 1991. Optimal twig-size selection of a generalist herbivore, the moose Alces alces: implications for plant - herbivore interactions. J. Anim. Ecol. 60: 395-408.

Wolff J. O. 1978. Burning and browsing effect on willow growth in interior Alaska. J. Wildl. Manage. 42: $135-140$.

Wolff J. O. and Cowling J. 1981. Moose browse utilization in Mount McKinley Park, Alaska. Can. Field-Nat. 95: 85-89.

Received 17 May 1993, accepted 24 January 1994. 